Nadwa | Jurnal Pendidikan Islam

Vol. 9, Nomor 2, Oktober 2015

\title{
Radikalisme Versus Pendidikan Agama Menggali Akar Radikalisme Dari Kekerasan Terhadap Anak Atas Nama Pendidikan Agama
}

\author{
Muhammad Thohir \\ UIN Sunan Ampel Surabaya \\ Email: muhammadthohir@uinsby.ac.id
}

\begin{abstract}
Education is not only limited to the pragmatic purposes for achieving various desired profession but also substantially, it aims to make a person more valuable in his life. Meanwhile, religion that considered as a greate and absolute value system was delivered particularly in different ways from the value itself. So, it will become the seeds of radicalism in the public interaction. This paper is the result of a conceptual development study that aimed to unravel the roots of radicalism by describing the children abuse facts in the process of religious education in Indonesia, both in family or school. The study explained the details of various aspects of the causes of the violent practices and analyzed it in religious, social and the educational management psychology perspectives.
\end{abstract}

Keywords: religious education, children violance, Radicalism

\begin{abstract}
Abstrak
Pendidikan tidak hanya terbatas pada tujuan pragmatis untuk mencapai berbagai profesi yang diinginkan, tetapi juga secara substansial, bertujuan untuk membuat seseorang lebih berharga dalam hidupnya. Sementara itu, agama yang dianggap sebagai sistem nilai yang besar dan mutlak disampaikan terutama dengan cara yang berbeda dari nilai itu sendiri. Jadi, itu akan menjadi benih-benih radikalisme dalam interaksi masyarakat. Tulisan ini merupakan hasil studi pengembangan konseptual yang bertujuan untuk mengungkap akar radikalisme dengan menggambarkan anak-anak penyalahgunaan fakta dalam proses pendidikan agama di Indonesia, baik dalam keluarga atau sekolah. Studi ini menjelaskan rincian berbagai aspek penyebab praktik kekerasan dan dianalisis dalam perspektif psikologi agama, sosial dan manajemen pendidikan.
\end{abstract}

Kata Kunci: Pendidikan Agama, Kekerasan Terhadap Anak, Radikalisme 


\section{Pendahuluan}

Kendati Indonesia telah meratifikasi konvensi hak anak dari Perserikatan Bangsa-Bangsa (PBB) selama 25 tahun, namun kekerasan terhadap anak justru terus meningkat. Oleh karena itu, Ketua Komisi Perlindungan Anak Indonesia (KPAI), Arist Merdeka Sirait pun telah menyatakan bahwa Indonesia sudah gawat darurat anak. ${ }^{1}$ Berdasarkan data yang telah dirilis oleh Wakil Ketua KPAI, Maria Advianti, tercatat bahwa dari tahun 2011 sampai tahun 2014, telah terjadi peningkatan yang signifikan, yaitu tahun 2178 kasus kekerasan (2011), 3512 kasus (2012), 4311 kasus (2013), dan 5066 kasus (2014).

Adapun 5 kasus tertinggi dengan jumlah kasus per bidang dari 2011 hingga april 2015, disebutkan bahwa kekerasan anak terkait dengan hukum 6006 kasus, pengasuhan 3160 kasus, pendidikan 1764 kasus, kesehatan dan NAPZA 1366 kasus serta pornografi dan cybercrime 1032 kasus. $^{2}$ Data kekerasan per bidang tersebut menampilkan sisi ironis karena ternyata kekerasan terhadap anak banyak terjadi proses pengasuhan dan pendidikan. Dengan kata lain, tempat kejadian perkara (TKP) justru biasa terjadi di dalam rumah dan lembaga pendidikan, yang seharusnya menjadi tempat paling aman bagi anak. Sebuah tempat atau lembaga dengan orang-orang yang seharusnya justru menjadi pelindung mereka, baik secara moral dan hukum ${ }^{3}$.

Di rumah dan lembaga pendidikan, proses pengasuhan dan pendidikan biasanya melibatkan para pelaku kekerasan yang telah dikenal dan berkedudukan lebih tinggi dari korban. Bahkan, kekerasan tersebut seakan terlegitimasi atas nama pendidikan agama. Akibatnya, tidak sedikit pihak-pihak yang permisif terhadap kasus

${ }^{1}$ Liputan6,.. 19/11/2014

2 kpai.go.id: 14/06/2015.

${ }^{3}$ Antara lain adalah UUD'45 pasal 28 B ayat 2: setiap anak berhak atas kelangsungan hidup, tumbuh dan berkembang serta berhak atas perlindungan dari kekerasan dan diskriminasi, UU 39/1999 tentang HAM pasal 52 ayat 1: setiap anak berhak atas perlindungan oleh orang tua, keluarga, masyarakat dan negara; ayat 2: hak anak adalah hak asasi manusia dan untuk kepentingannya hak anak itu diakui dan dilindungi oleh hukum, bahkan sejak dalam kandungan, UU 23/2002 tentang perlindungan anak, pasal 77, 78, 83, 84, 87, 88 dan 89; vide pasal 306 jo pasal 304, 403 KUHP, serta Undang-Undang Nomor 35/2014 tentang Perlindungan Anak yang telah mengakomodir seluruh hak anak dan kewajiban orang dewasa terhadap anak, disertai sanksi tegas terhadap pasal-pasal pelanggaran. 
kekerasan terhadap anak karena dianggap tak lebih sebagai masalah aib keluarga atau lembaga pendidikan yang harus ditutup-tutupi. Oleh karena itu, berbagai rilis data data tentang jumlah kekerasan dalam proses pengasuhan dan pendidikan yang telah diungkap, bisa jadi bukan merupakan jumlah sebenarnya terjadi di masyarakat. Sikap permisif masyarakat dianggap mengakibatkan peningkatan jumlah kasus-kasus terkait. Kalau mau jujur, mungkin saja data kekerasan terhadap anak dalam proses pendidikan di keluarga dan sekolah menempati jumlah dengan rangking tertinggi.

Sementara itu, gerakan radikalisme di Indonesia semakin mendapat sorotan. Kendati tokoh-tokoh penting yang menjadi pentolan kelompok radikal, seperti Jamaah Islamiyah (JI) telah dilumpuhkan, namun radikalisme seakan tetap bermetamorfosis dalam sel-sel baru. Azyumardi Azra ${ }^{4}$ menyebutkan mereka malah bergerak sendiri-sendiri secara independen meskipun satu sama lainnya berkaitan. Penelusuran radikalisme di Indonesia semakin kompleks karena selalu dikaitkan dengan pergolakan internasional, khususnya dari negara-negara di Timur Tengah. Setelah kelompok Taliban tumbang, muncul kembali kelompok yang menamakan diri dengan the Islamic State of Irak and Suriah (ISIS) melakukan berbagai aksi yang sangat mengkhawatirkan dunia internasional, termasuk di Indonesia.

Menurut sumber Tempo ${ }^{5}$ warga negara Indonesia (WNI) yang telah bergabung dengan ISIS telah teridentifikasi POLRI sebanyak 159 orang. Data ini dikantongi POLRI pasca penelusuran lebih lanjut setelah kasus 16 WNI tertangkap oleh Pemerintah Turki saat hendak menyeberang ke Suriah untuk bergabung dengan ISIS. Dari 16 WNI tersebut, 12 orang langsung dideportasi ke tanah air dan diikutkan program deradikalisasi. Sedangkan kepulangan 4 WNI yang lain disusulkan kemudian karena sedang hamil tua. Hal yang unik di sini adalah, jika sebelumnya radikalisme internasional merekrut anggota-anggota secara perorangan tanpa sepengetahuan pihak keluarga, maka kali ini rekrutmen dilakukan langsung terhadap

${ }^{4}$ Azyumardi Azra, Akar Radikalisme Keagamaan: Peran Aparat Negara, Pemimpin Agama dan Guru untuk Kerukunan Umat Beragama,. Makalah dipresentasikan pada Workshop Memperkuat Toleransi melalui Institusi Sekolah, Bogor, 14 - 15 Mei 2011. Diselenggarakan oleh The Habibi Center, bekerjasama dengan Hans Seidel Foundation, (Tidak dipublikasikan), hlm. 2

${ }^{5}$ Tempo, 30/03/2015. 
kelompok dalam sebuah ikatan keluarga, tidak hanya yang berusia dewasa, tetapi juga mereka yang masih kanak-kanak.

Sedangkan fenomena radikalisme yang bergeser ke lembagalembaga pendidikan, patut diperhitungkan berbagai temuan soal materi ajar dalam buku mata pelajaran agama yang memuat paham intoleransi dan radikalisme. Selain itu, data hasil penelitian survey Lembaga Kajian Islam dan Perdamaian (LaKIP) Jakarta tahun 2010 perlu digarisbawahi. Temuannya sungguh mengkawatirkan, karena sebanyak 48,9\% siswa se wilayah Jabodetabek menyatakan persetujuannya terhadap aksi radikal. ${ }^{6}$ Fenomena di atas meninggalkan sebuah pertanyaan penting, mengapa rekrutmen gerakan radikalisme beralih ke keluarga dan sekolah. Adakah kaitannya dengan pola-pola tindak kekerasan terhadap anak? Untuk itu, makalah ini mencoba mengurai bagaimana paham-paham radikalisme berpotensi tumbuh akibat pola kekerasan 'berbaju agama' terhadap anak.

\section{Kekerasan 'Berbaju' Agama Terhadap Anak}

Dalih kekerasan terhadap anak dalam proses pengasuhan dan pendidikan yang sering digunakan adalah karena anak nakal. Anak yang melakukan pelanggaran norma-norma keagamaan disikapi dengan tindakan kekerasan atas nama agama itu sendiri. Tindakan kekerasan dianggap merupakan bagian dari proses dalam mendidik agama, sehingga muncul persepsi bahwa jika kenakalan seorang anak tidak disikapi atau diperlakukan dengan keras, baik langsung maupun tidak langsung, maka tidak akan terjadi perubahan di dalam dirinya.

Kekerasan langsung, misalnya, seorang bocah (5 tahun) di Kabupaten Singkawang terpaksa dilarikan dari rumahnya ke rumah sakit setelah dipukul dan disudut rokok oleh sang ayah, UN (31 tahun). Hal itu dilakukan karena si anak suka pipis di celana. ${ }^{7}$ Sedangkan di sekolah, MBF (9 tahun), siswa kelas IV SDN Kepatihan Banyuwangi dihajar gurunya, SR karena dianggap nakal telah mendorong teman sekelasnya hingga terjatuh. ${ }^{8}$ Sementara N (10 tahun) telah ditampar oleh D, guru agama yang juga Wali Kelas di sebuah SDN di Jakarta Timur karena melempari teman sekelas

${ }^{6}$ Abdul Munip, "Menangkal Radikalisme Agama Di Sekolah", dalam Jurnal Pendidikan Islam, (Vol. I, No. 2, Desember 2012), hlm. 160.

${ }^{7}$ Kompas, 30/09/2013

${ }^{8}$ detik.com, 02/08/2010 
dengan penghapus. ${ }^{9}$ Tindak kekerasan di pesantren, misalnya di Kabupaten Jombang, tiga santri telah dicambuk guru agamanya karena dianggap melanggar norma agama. Peristiwa yang sempat menghebohkan di akhir Desember 2014 lalu itu pun mengundang keprihatinan banyak pihak, sehingga MUI Kabupaten Jombang turut menginvestigasi pihak pesantren. ${ }^{10}$ Peristiwa kekerasan serupa juga menimpa pada SQ (14 tahun) di sebuah pesantren di Kabupaten Situbondo, sang guru agama telah memukulinya hingga babak belur karena alasan yang bersangkutan telah melanggar agama dengan mencuri handphone. ${ }^{11}$

Sedangkan kekerasan tidak langsung dapat dijumpai seperti dalam kasus pentas seni siswa di Sekolah Dasar Islam As-Shafa, Depok, Jawa Barat. Dalam pentas tersebut dianggap telah tersusupi tema radikalisme, kendati Kepala Sekolah telah membantahnya bahwa hal itu tak lebih dari pembelajaran solidaritas terhadap korban perang di Palestina. ${ }^{12}$ Selain itu juga ada yang berbentuk buku, seperti buku pendidikan agama Islam kelas XI SMA yang isinya berbau kekerasan dan telah beredar di sejumlah sekolah di Jombang, Jawa Timur. Selain dianggap memuat materi intoleransi, pada halaman 78, dijelaskan orang yang menyembah selain Allah atau non muslim boleh dibunuh. Buku tersebut sudah ditarik kembali oleh pemerintah atas intruksi Menteri Pendidikan dan Kebudayaan (Mendikbud), Anies Baswedan. ${ }^{13}$

Adapun yang terbaru adalah berita bagaimana sekolah-sekolah usia dini (taman kanak-kanak) telah disusupi ideologi radikalisme melalui buku-buku yang digunakan. Temuan ketua GP Ansor Depok tersebut memperlihatkan buku latihan menulis dan merangkai kata itu mengandung 32 kata yang tak pantas untuk usia anak-anak. Kata-kata tersebut mengarahkan kepada benih-benih radikalisme, di antaranya adalah 'sabotase', 'bom', 'sahid di medan jihad', 'rela mati bela agama', 'gegana ada di mana', 'bila agama kita dihina kita tiada rela', 'basoka dibawa lari', dan 'selesai raih bantai kiyai'. ${ }^{14}$ Buku

\footnotetext{
${ }^{9}$ beritasatu.com, 26/08/2014

10 sindonews.com, 07/12/2014

11 madiunpos.com, 08/03/2015

12 tempo.co, 17/08/2015

13 okezone.com, 21/03/2015

${ }^{14}$ Detiknews, 20/01/2016
} 
ini lalu mendapat perhatian serius dari Mendikbud sehingga terbit surat edaran pelarangan penggunaanya di sekolah. ${ }^{15}$

Jika kekerasan tidak langsung pada anak ini tidak boleh diremehkan karena anak adalah masa potensial pembentukan karakter, apalagi kekerasan langsung pada anak. Hanya saja, kekerasan langsung pada anak ternyata lebih banyak diperhatikan adalah yang lebih berakibat kerugian fisik dan material dari pada kerugian psikis atau mental. Faktanya, laporan bukti kerugian fisik lebih cepat direspon dari pada bukti-bukti lainnya oleh masyarakat dan pihakpihak yang berwenang. Padahal, kekerasan dengan kerugian psikis atau mental itu disinyalir justru lebih sering terjadi, seperti ungkapan lisan yang kasar (verbal abuse) dalam proses pengasuhan dan pendidikan. Berbagai keterangan saksi tentang kekerasan non fisik seakan menguap sehingga susah mendapatkan tindakan hukum. Aparat hukum pun lebih memilih data-data fisik sebagai alat bukti untuk penindakan hukum dan mengabaikan laporan-laporan kekerasan yang bersifat psikis, meski diketahui secara jangka panjang juga berakibat fatal, dimulai dari tidak nafsu makan, ketakutan, rendah diri, depresi, trauma, sampai melukai diri sendiri (bunuh diri) atau bahkan orang lain.

Baik fisik maupun psikis, ketika kekerasan terhadap anak itu terjadi diatasnamakan sebagai pendidikan agama, maka pihak berwenang seperti kehilangan gairah investigatifnya terhadap kekerasan yang terjadi. Meskipun di sekitarnya telah banyak yang melihat atau mendapatkan laporan kejadian kekerasan, biasanya ada kecenderungan kompromi atau bahkan menutup-nutupi. Kondisi semacam inilah yang disesalkan oleh Bette L. Bottoms, Michael Nielsen and Rebecca Murray, Henrietta Filipas ${ }^{16}$ dalam simpulan hasil riset mereka bahwa kekerasan fisik karena alasan agama tidak menarik perhatian pihak berwenang karena dianggap sebagai sebuah kewajaran meski dalam jangka panjang disadari dapat berakibat gangguan psikologis.

\section{Diagnosis Diferensial Dampak Kekerasan Terhadap Anak}

Barangkali, kita semua sepakat bahwa kekerasan terhadap anak secara fisik akan memiliki dampak trauma langsung dan yang

${ }^{15}$ Kompas, 21/01/2016

${ }^{16}$ Lihat pada Bette L. Bottoms, Michael Nielsen and Rebecca Murray, Henrietta Filipas. "Religion-related Child Physical Abuse: Characteristics and Psychological Outcomes." Journal of Aggression, Maltreatment, and Trauma. Janet Mullins (Ed.), (New York: Binghamton Press. 2003), hlm. 27 
secara psikis tidak berdampak langsung. Trauma fisik berupa luka, patah tulang, cacat atau bahkan sampai meregang nyawa merupakan contoh dampak akibat kekerasan secara fisik. Namun trauma psikis biasanya tidak spontan dapat terlihat. Memang tidak mudah untuk mengetahui tanda-tanda kekerasan psikis terhadap anak itu terjadi dan kapan anak bisa dikatakan mengalaminya. Apalagi, aspek normatif keagamaan dan kultural sering menjadi ideologi pembenar bagi kebanyakan masyarakat atas tindak kekerasan tersebut. Meskipun demikian, sebenarnya, seorang anak bisa dikatakan mengalami kekerasan apabila kemarahan, hinaan atau ancaman orang di sekitar anak terjadi secara terus menerus (persistence) sehingga dalam jangka panjang merusak mentalnya. Untuk itu, atas dasar cakupan trauma psikis inilah, diksi abuse dalam tulisan ini lebih dipilih sebagai makna kekerasan daripada violence yang sering digunakan merujuk pada makna kekerasan secara umum.

Karena child abuse itu juga menyakut kekerasan mental, maka Finzi, Har-Even, dan Weizman lebih memilih kata 'pelecehan' sebagai terjemahan kata abuse. Dia mendistingsikan antara abused children 'pelecehan anak' dengan neglected children 'penelantaran anak'. Menurutnya, dalam beberapa hal memang terdapat kemiripan antara keduanya, yaitu saat anak-anak yang dilecehkan sering pula ditelantarkan. Namun, anak-anak yang terlantar belum tentu mengalami pelecehan. Oleh karena itu, keduanya dia kategorikan sama-sama sebagai maltreated children 'ketidaklayakan perlakuan terhadap anak'. Tentu saja, maltreated children ini sangat mengganggu pertumbuhan anak. Gangguan tersebut mencakup (1) gangguan afeksi, (2) pengendalian diri rendah, (3) distorsi dalam melihat realitas, dan (4) ketidakmatangan mekanisme pertahanan ${ }^{17}$.

Adapun gangguan afektif adalah perasaan mudah tersinggung, gampang marah, depresi dan cenderung pasif. Dari berbagai fakta yang ada menunjukkan bahwa anak yang mengalami gangguan afektif sering berperilaku merajuk atau bersikap tidak peduli dan masa bodoh. Gangguan tersebut bisa berkembang dan menjadikan anak tidak lagi mampu mengendalikan dirinya. Marah-marah, berteriak, membentak atau bahkan menyerang secara fisik cenderung dilakukannya sebagai bentuk ketidakberdayaan anak terhadap dorongan berperilaku (impuls) yang muncul.

17 Monty P. Satiadarma, “Anak-anak Terlantar”, dalam Singgih D Gunarsa (Ed)., Dari Anak Sampai Usia Lanjut, (Jakarta: BPK Gunung Mulia, 2004), hlm. 115-117 
Sedangkan distorsi dalam melihat realitas adalah ketika seorang anak tidak lagi berkemampuan untuk membedakan mana perhatian, penghargaan dan kasih sayang sebenarnya dari orang di sekitarnya atas apa yang dia lakukan, apakah itu baik atau salah. Hal ini disebabkan oleh pemberian perhatian, penghargaan dan kasih sayang orang tua atau guru yang tidak proporsional. Karena perhatian orang tua atau guru justru lebih besar ketika anak melakukan kesalahan, maka anak cenderung mengembangkan perilaku-perilaku yang salah itu untuk mendapatkan perhatian yang diharapkan.

Adapun gangguan yang berupa ketidakmatangan mekanisme pertahanan seringkali berupa regresi, penyangkalan, proyeksi dan introjeksi. Regresi mengacu kepada kemunduran ke arah bentuk perilaku kekanak-kanakan seperti menghisap jempol meskipun anak sudah menginjak usia sekolah lanjutan. Penyangkalan sering dilakukan dalam bentuk kata-kata dusta atau berbohong. Proyeksi sebagai bentuk perilaku yang cenderung menyalahkan orang lain. Sedangkan introjeksi merupakan pengambilalihan nilai dari lingkungan sosial anak. Misalnya, karena anak selalu dibentak dan dihardik ketika dianggap mengganggu aktifitas orang tua, maka anak pada saat lain akan membenarkan tindakan membentak ataupun menghardik teman-teman yang dianggap mengganggunya.

Empat kategori maltreated children di atas akan semakin tersulut manakala kondisi dan lingkungan anak justru tidak suportif. Banyak orang tua dan para guru yang tidak menyadarinya, bahwa tindakan anak yang dianggap nakal itu tak lebih sebagai 'jalan' bagi mereka meluapkan emosinya. Terkadang, mungkin saja apa yang mereka lakukan itu karena spontan meniru adegan kekerasan dari sumber bacaan, sumber tontonan TV, dari temannya atau bahkan dari guru dan orang tuanya sendiri. Kurang terdeteksinya kekerasan mental lebih awal membuat korban baru diketahui setelah yang dideritanya sudah parah dan kronis. Gejalanya antara lain anak gampang terbangun di malam hari, suka mengompol meski sudah berusia sekolah lanjut, suka menyangkal atau sebaliknya terlalu penurut, agresif berlebihan bahkan sampai mencederai diri atau orang lain. Kondisi mental inilah yang penulis anggap berpotensi menjadi benih-benih radikalisme di kemudian hari.

\section{Relasi Radikalisme dengan Kekerasan Terhadap Anak}

Dalam bagian ini, penulis mengajukan hipotesis bahwa terdapat relasi radikalisme dengan kekerasan terhadap anak. Mari ditelusuri 
kembali berbagai sumber literer, bagaimana sebuah gerakan radikalisme terjadi. Azyumardi Azra ${ }^{18}$ menegaskan bahwa akar radikalisme itu setidaknya bersumber dari empat hal, yaitu: (1) pemahaman keagamaan sempit yang literal dan sepenggal-sepenggal terhadap ayat-ayat al-Qur'an, (2) bacaan yang salah terhadap sejarah Islam yang dikombinasikan dengan idealisasi berlebihan terhadap Islam pada masa tertentu, (3) argumentasi deprivasi politik, sosial dan ekonomi yang masih bertahan dalam masyarakat, dan (4) disorientasi dan dislokasi sosial budaya akibat globalisasi. Pada poin satu dan dua, radikalisme bermuara pada level pemikiran (radical competence). Sedangkan pada level tiga dan empat, radikalisme bermuara pada level tindakan dan situasi (radical performance).

"Religion and child abuse, perfect together," demikian pernyataan Donald Capp sebagaimana dikutip oleh Bette L. Bottoms, Philip R. Shaver, Gail S. Goodmans, dan Jian Jian Qin dalam tulisannya yang berjudul In the Name of God: A Profile ReligionRelated Child Abuse. ${ }^{19}$ Pernyataan tersebut mengindikasikan relasi yang kuat antara cara pemahaman keagamaan dan praktik tindakan kekerasan terhadap anak. Posisi anak dalam keluarga atau sekolah, bisa sebagai korban kekerasan, juga bisa sebagai pelaku kekerasan, utamanya di masa-masa mendatang. Dengan kata lain, mereka yang telah melakukan tindak kekerasan adalah mereka yang telah menjadi korban sebelumnya.

Para guru yang melakukan tindak kekerasan kepada anak didiknya, sangat mungkin dulunya juga pernah menjadi korban kekerasan sehingga mengalami apa yang disebut dengan sindrom 'ketidakmatangan mekanisme pertahanan', baik secara proyektif dengan suka menyalahkan pihak lain atau secara introjektif dengan menganggap kekerasan yang dilakukan sebagai hal yang lumrah.

Individu-individu yang tumbuh berkembang dengan 'ketidakmatangan mekanisme pertahanan' akan semakin mudah 'terinfeksi' paham-paham radikal. Ketidaknormalan psikologis mereka tidak selalu terlihat dan disadari oleh lingkungannya, sehingga seringkali masyarakat lebih melihat mereka sebagai

${ }^{18}$ Azra, Akar Radikalisme Keagamaan: Peran..., hlm. 3-4

${ }^{19}$ Bette L. Bottoms, Philip R. Shaver, Gail S. Goodmans, dan Jian Jian Qin, "In the Name of God: A Profile Religion-Related Child Abuse", Journal of Social Issues, (Vol. 5, No. 2, 1995), hlm. 86 
orang baik dan santun meski terkadang agak tertutup dan pendiam.

Kasus pelaku bom bunuh diri dengan keyakinan sebagai 'sang pengantin' adalah bukti tak terbantahkan dari korban kekerasan. Kasus Wildan Mukhollad (19 tahun), misalnya, dia adalah di antara dari sekian banyak individu yang tewas karena terseret oleh ideologi 'sang pengantin' bom ISIS di Suriah. Meski kematiannya membuat shock keluarganya, ${ }^{20}$ namun pengakuan kakaknya, In'am, disebutkan bahwa Wildan semasa kecil setelah mengenyam pendidikan di pesantren Amrozi (salah satu pelaku bom Bali II), menyatakan bercita-cita untuk berjihad di Timur Tengah.

Biasanya, kelabilan psikologis sang pelaku bom bunuh diri membuat lebih mudah dicekoki bahwa ada kebahagiaan abadi dengan surga terbentang dipenuhi 72 bidadari menanti di balik ledakan bom. Mereka diajari bahwa kematian pun tidak lebih terasa seperti cubitan yang tidak menyakitkan. Karenanya, AKBP Arif Nurcahyo, Kabag Psikologi, Sumber Daya Manusia Polda Metro Jaya, menganggap bahwa yang mejadi target kelompok teroris sebagai calon 'Sang Pengantin' baru adalah mereka yang secara personal cenderung tertutup dan pendiam, atau setidaknya pernah dikucilkan (neglected) dari lingkungannya. ${ }^{21}$ Misalnya pada kasus Muhammad Syarif, pelaku bom bunuh diri di Masjid Ad-Zikra sebagai sosok yang jarang bergaul dengan tetangga, suka marah pada ibunya, dan tidak mau shalat di masjid kampungnya sendiri. ${ }^{22}$

Gejala faktual psikologis yang menjadi latar belakang para calon 'Sang Pengantin' bom bunuh diri ini sampai diilustrasikan secara apik oleh Jatmika dalam tulisan fiksinya, Pengantin Bom: Sebuah Novel Sosio-Kriminologi. Dalam novel tersebut, diceritakan bahwa Warson Kemin (30 tahun), sosok fiktif yang menggambarkan figur calon pelaku bom bunuh diri merupakan pemuda yang lemah sahyat dan degleng (kurang waras) karena suka bicara sendiri. Bahkan menurut Simbok Tentrem, Warso sebelum menikah Warso pernah melakukan percobaan bunuh diri tanpa dimengerti oleh sekitarnya apa sebab dia melakukannya. ${ }^{23}$ Tentu saja,

${ }^{20}$ liputan6.com, 14.08.2014

${ }^{21}$ merdeka.com, 7/09/2012

${ }^{22}$ suaramerdeka.com, 16/04/2011

${ }^{23}$ Sidik Jatmika, Pengantin Bom: Sebuah Novel Sosio-Kriminologi, (Yogyakarta: Liberplus, 2009), hlm. 28-30 
kondisi psikologis yang menyimpang pada mereka bukanlah sesuatu yang datang secara tiba-tiba, tetapi merupakan akibat dari sebuah perlakuan kekerasan yang terjadi secara persistence pada mereka seperti yang telah disinggung dalam diagnosis diferensial di atas.

\section{Revitalisasi Keluarga dan Manajemen Lembaga Pendidikan Ramah Anak}

Pendidikan agama bagi anak-anak merupakan tanggungjawab bersama, terutama bagi orang tua di rumah dan para guru di sekolah. Orang tua sebagai pengendali utama dalam keluarga sangat berperan penting dalam mengarahkan putera-puterinya pada pencapaian nilai-nilai keagamaan. Demikian juga dengan sekolah, para guru mengambil posisi penting di kelas. Apalagi di level pendidikan dasar seperti SD dan MI, guru bukan hanya sebagai pengajar namun juga seringkali dijadikan top figur oleh siswa mengalahkan pengaruh orang tua siswa sendiri. Karenanya, guru sangat berperan penting sebagai sumber kurikulum.

Hanya saja, peran penting dan strategis tersebut tidak selalu sesuai harapan. Orang tua yang seharusnya bagi anak menjadi pendamping dan pelindung, malah menjadi sosok ancaman sehingga anak di rumah menjadi tak betah dan tak nyaman. Sementara guru di sekolah yang diharapkan apat membantu peran orang tua, faktanya tidak sedikit yang malah lebih kejam dari orang tua siswa. Ironisnya, perilaku tersebut diatasnamakan pendidikan agama.

Secara psikologis, orang tua dan guru yang suka mengancam dan memarahi anak, biasanya pernah menjadi korban kekerasan yang serupa di saat mereka kanak-kanak. Mereka menjadi introjektif dengan menganggap sebuah kecaman, hinaan atau amarah kepada anak-anak atau siswa sebagai keniscayaan. Selain itu, sikap posesif yang berlebih-lebihan terhadap anak juga cenderung membuat orang tua gagal membedakan antara cara mendidik anak atau menghajarnya. Harapan orang tua yang terlalu tinggi atas anak, juga menambah deretan perlakuan mereka secara otoriter, sehingga seakan tidak ada ruang komunikasi dialogis, karena anak atau siswa harus menuruti apa saja yang disampaikan orang tua dan guru.

Orang tua dan guru seharusnya menyadari bahwa anak sebagai individu yang sedang dalam proses tumbuh dan berkembang, tentu mereka belum mampu berpikir dan merasakan dalam batas dunia 
pikiran orang tua dan guru. Kurangnya pengetahuan mereka terhadap pertumbuhan anak mengakibatkan ketidakpekaan terhadap apa yang sedang dibutuhkan oleh anak.

Bahkan yang lebih memprihatinkan lagi, ada kalanya orang tua dan guru sering tidak menyadari bahwa justru ada ketidakberesan dengan diri mereka sendiri, misalnya gangguan kepribadian. Akibat tekanan persoalan ekonomi, sosial, dan politik sebagaimana terjadi dewasa ini, sering tidak disadari telah merubah kepribadian atau bahkan gangguan kejiwaan mereka. Ujung-ujungnya, cacian, kecaman dan amarah terhadap anak sering digunakan sebagai pelepas emosi atau tekanan mental yang ada. Persoalan insight orang tua dan guru yang buruk ini kadang diperparah lagi oleh ketergantungan alkohol atau narkoba. Dengan demikian, keluarga tak lagi mampu memerankan diri sebagai keluarga. Kondisi seperti inilah yang oleh Satiadarma disebut dengan 'disfungsi keluarga'. ${ }^{24}$ Oleh karena itu, keluarga dan sekolah perlu diposisikan lagi sesuai perannya dengan meluruskan kembali penyimpangan-penyimpangan yang ada.

Jika penyimpangan itu sampai pada tahap 'disfungsi keluarga', maka seharusnya ada pendampingan dari pihak atau lembaga terkait terhadap keluarga tersebut. Cuma rumitnya adalah proses pendekatan awal dan pelaksanaan pendampingan yang sering terkendala oleh ekslusifisme mereka. Pendampingan tidak boleh dilakukan hanya pada anak yang menjadi korban. Namun, para orang tua dan guru juga seharusnya mendapatkan perhatian, terutama dalam memulihkan psikologi mereka dan membekali mereka dengan materimateri anti kekerasan dan deradikalisasi dalam pengasuhan anak. Mereka harus mengetahui bahwa cara-cara mengasuh dan mendidik anak dengan cara-cara kekerasan justru kontradiktif dengan nilainilai keagamaan itu sendiri.

Sebagai contoh, soal menghadapi reaksi anak saat menangis, stigma yang diberikan orang tua adalah anak nakal dan sulit diatur. Padahal, tindakan menangis itu sebagai salah satu pola tantrum ${ }^{25}$

${ }^{24}$ Satiadarma, "Anak-anak Terlantar...”, (hlm. 113

${ }^{25}$ Tantrum (bahasa Jawa: ngadat, ngambek) merupakan bentuk luapan emosi anak yang bertujuan untuk memaksa orang lain. Bentuk tantrum berpola sesuai dengan perkembangan usia anak. Misalnya, anak dibawah usia 3 tahun mengalami tantrum dengan cara menggigit, memukul, menendang, menjerit, menghempaskan badan ke lantai, memukul-mukulkan tangannya dan lainlain. Lihat Singgih D. Gunarso, Psikologi Anak Bermasalah, (Jakarta: BPK Gunung Mulia, 1985), hlm. 69-89 
mereka yang perlu mendapat perlakuan yang proporsional dan hatihati. Sebab, tangisan yang berlebih-lebihan sesungguhnya akan sangat merugikan anak baik fisik ataupun psikologis. Kerugian yang terjadi misalnya anak akan kehabisan tenaga yang menyebabkan gangguan homeostatis ${ }^{26}$. Perlakuan tersebut akan menghancurkan pribadi anak di kemudian hari. Hal inilah yang diperingatkan oleh Nabi Muhammad saw, sebagaimana dinukil oleh M. Quraish Shihab, dalam bukunya Wawasan Al-Quran: Tafsir Maudhu'i atas Perbagai Persoalan Umat, bahwa kekerasan meskipun sebatas verbal akan mengeruhkan jiwa anak. ${ }^{27}$

Sebagian orang tua dan guru menjustifikasi tindak kekerasan terhadap anak dalam pendidikan agama dengan merujuk hadits 'allimū al-shabiyya al-shalāta ${ }^{28}$. Berdasarkan lafadh idlribū hum 'alayh $\bar{a}$ 'memukul anak' untuk perintah menunaikan shalat jika saat berusia 10 tahun, maka orang tua seakan tidak merasa bersalah memukul anak-anak mereka. Jika perintah memukul anak itu dibenarkan oleh Nabi saw, tetapi mengapa penulis belum menemukan satu riwayat pun yang memberitakan Nabi pernah memukul anak atau cucunya.

Barangkali, tarjih ulang atas hadits yang menurut perawinya sebagai hadits berderajat hasan itu diperlukan. Sebab, secara lughawiy, kata idlribū yang berasal dari dlaraba ternyata tidak selalu

${ }^{26}$ Yaitu disfungsi normal keseluruhan tubuh seperti variabilitas fungsi gastrointestinal, regurgitations, muntah-muntah, ngompol, dan ketegangan syaraf umum yang ditandai dengan menghisap jempol atau menggigiti kuku. Sedangkan kerugian psikologis di antaranya adalah anak akan merasa tidak berdaya dan tidak aman akibat amarah atau pengabaian orang tua atas tangisan mereka yang kemudian ditafsirkan anak sebagai penolakan orang tua, atau anak merasa tidak diinginkan dan tidak disenangi. Lihat: Elizabeth B.Hurlock, Perkembangan Anak, alih bahasa: Tjandrasa dan Zarkasih, (Jakarta: Erlangga, 1995), hlm. 194-195

${ }^{27}$ Disebutkan dari Ummi Fadlal (ra), bahwa seorang anak telah pipis di pangkuan Rosulullah sehingga membasahi pakaian beliau. Sang ibu kemudian merenggutnya dari pangkuan Rosulullah dan memarahinya dengan kasar. Rosulullah sangat tidak berkenan dengan pemandangan itu, sehingga dia bersabda: "Jangan engkau menghentikan pipisnya. Pakaian ini dapat dibersihkan dengan air, tetapi apakah yang dapat menghilangkan kekeruhan dalam jiwa anak ini akibat perlakuan kasar itu?" lebih lanjut buka, M. Quraish Shihab, dalam bukunya Wawasan Al-Quran: Tafsir Maudhu'I ats Perbagai Persoalan Umat, (Bandung: Mizan, 1997), hlm. 312

${ }^{28}$ Redaksi lebih lengkap dari hadits ini adalah 'allimū al-shabiyya alshalāta li sab'i sinīna wa idlribū hum 'alayhā wa hum abnā'u 'asyarin wa farriqū bayna hum fi al-madlāji' (HR. Abu Dawud dan Al-Turmudzi) 
berarti 'memukul'. Bahkan secara leksikologis, jika kata tersebut bersanding dengan alā dan al-shalāta, maka artinya menjadi aqāma 'menegakkan'29. Jika perintah shalat saat anak berusia 10 tahun itu berarti menegakkan, maka proses relasi edukatif orang tua anak lebih kokoh, karena anak tak sebatas meniru orang tuanya shalat, namun mereka berupaya lebih memaknai shalatnya dan posisi orang tua dan guru lebih memerankan sebagai pelindung, pendamping dan teladan. Terutama, dalam konteks menghadapi dinamika pergeseran budaya dan derasnya arus tayangan kekerasan di media massa, mereka justru tidak boleh larut di dalamnya.

Untuk menghadapi dinamika di atas, sekolah seharusnya mampu membenahi manajemen kurikulumnya. Secara pendekatan manajemen strategis, setidaknya kurikulum itu dipilah dan dipilih dengan melihat realitas konteks problematika yang ada, baik secara mikro, messo dan makro. Secara mikro adalah bagaiamana desain teknologi pembelajaran, sikap dan persoalitas para staf pengajar, butir materi yang diajar, sumber-sumber pembelajaran, semuanya harus melalui proses yang matang. Proses mikro ini dapat didukung dengan pemberdayaan lesson study di antara sesame guru atas apa yang diajarkan. Secara messo adalah bagaimana tatakelola kontrol dari dinas pendidikan pemerintahan daerah setempat. Mereka bertanggungjawab dengan dinamika tranformasi sekolah di daerahnya. Untuk itu, seyogyanya berbagai kebijakan ataupun peraturan daerah dapat mendukung system manajemen pendidikan yang ramah anak. Adapun secara makro adalah kontkes yang lebih luas, yaitu peraturan-peraturan dan isu nasional terkait dengan program pendidikan nasional dan juga berbagai isu internasional.

Oleh karena itu, revitalisasi peran orang tua menjadi sangat urgen dalam konteks ini, baik di dalam mendidik anak-anaknya di dalam rumah, ataupun dalam mengkontrol proses pendidikan anakanak mereka di sekolah. Sedangkan revitalisasi pihak sekolah dapat dilakukan dengan berbenah diri dan meninjau ulang kurikulum di dalamnya, misalnya dengan SWOT analysis untuk mengerti berbagai peluang dan tantangan yang sedang dan akan dihadapi sekolah seperti disinggung dalam paragraf sebelumnya.

Sekolah tidak boleh mudah terbawa isu dan ideologi transnasional, terutama yang mengarah pada radikalisme dan terorisme.

${ }^{29}$ Louis Ma'luf, Al-Munjid fi al-lughah wa al-A'lām, (Beirut: Dar al Masyriq, 1986), hlm. 448 
Pihak-pihak yang bertanggungjawab dalam sekolah harus memiliki kepekaan melalui berbagai metode analisis dalam proses internal kurikulumnya. Jika tidak, maka sekolah dapat dengan mudah 'kecolongan' oleh berbagai macam trik dan upaya masuknya idelogi radikalisme.

Kasus bantahan Kepala Sekolah di salah satu SD Islam, Depok, Jawa Barat yang mementaskan aksi teatrikal bersenjata ala perang Palestina versus Israel sebagai tak lebih dari pembelajaran solidaritas terhadap korban perang mengindikasikan semakin menipisnya kepekaan terhadap isu radikalisme. Sekolah seakan lebih terbawa oleh isu transnasional yang sangat mungkin tidak bersih dari muatan-muatan ideologi kekerasan. Jika dimaksudkan sebagai upaya pendidikan solidaritas sesama muslim, kenapa tidak bisa lebih diarahkan dengan tema-tema pengorbanan para pahlawan nasional dengan atraksi yang lebih elegan. Bukankah korban di saat para pahlawan itu berjuang, tidak sedikit nyawa umat Islam yang melayang. Dengan cara ini, guru tidak lagi sekedar mendidikan anakanak solidaritas sesama muslim, tapi juga mengajari mereka mencintai agama dan dan menghargai sejarah bangsanya.

\section{Penutup}

Secara hipotetik, terdapat relasi yang linear antara fenomena kekerasan terhadap anak-anak dengan berkembangnya radikalisme. Atas nama pendidikan agama, ada dua model kekerasan pada anak yang sangat berpotensi menjadi bibit-bibit radikalisme. Pertama, metode mendidik orang tua dan guru seringkali tanpa disadari telah melakukan tindak kekerasan, baik fisik, mental atau verbal. Kedua, mengalirnya muatan-muatan idiologi radikal yang sistemik dalam pelajaran atau kurikulum sekolah yang semakin komplek akibat kontekstualisasi globalisme yang tak selektif. Apalagi, sikap masyarakat cenderung semakin permisif sehingga hanya bisa shock saat mengetahui anak-anak semakin besar semakin introjektif. Remaja tanggung seperti itulah yang kemudian menjadi target empuk calon anggota jaringan radikal.

Untuk itu, revitalisasi keluarga dan sekolah dalam peran dan fungsinya dalam pendidikan anak perlu diperhatikan, terutama terkait dengan pergeseran idiologi, misinterpretasi dalil-dalil keagamaan, dan prevensi atas derasnya arus informasi bermuatan radikal. Sebagai implikasi dari kajian ini, semua pihak harus secara bersama-sama membangun kembali peran dan fungsi keluarga dan 
sekolah dengan memberikan pendampingan dan pengarahan. Program deradikalisasi oleh pemerintah tak cukup hanya diberikan oleh pemerintah terhadap mereka para pelaku teroris yang tertangkap. Namun, juga diperlukan adanya sebuah program nasional yang terukur tentang sosialisasi dan pembinaan pada seluruh lapisan masyarakat untuk mengantisipasi potensi radikalisme tersebut dimulai dari dalam keluarga dan sekolah.

\section{Kepustakaan}

Azra, Azyumardi. 2011, Akar Radikalisme Keagamaan: Peran Aparat Negara, Pemimpin Agama dan Guru untuk Kerukunan Umat Beragama, hal:2. Makalah dipresentasikan pada Workshop Memperkuat Toleransi melalui Institusi Sekolah Bogor, 14 - 15 Mei 2011.

Bottoms, Bette L. and Michael Nielsen and Rebecca Murray, Henrietta Filipas, 2003. "Religion-related Child Physical Abuse: Characteristics and Psychological Outcomes", Journal of Aggression, Maltreatment, and Trauma. Janet Mullins (Ed.), New York: Binghamton Press.

Bottoms, Bette L. Philip R. Shaver, Gail S. Goodmans, dan Jian Jian Qin, 1995 "In the Name of God: A Profile Religion-Related Child Abuse", dalam Journal of Social Issues, Vol. 5, No, 2.

Gunarso, Singgih D. 1985, Psikologi Anak Bermasalah, Jakarta: BPK Gunung Mulia.

Hurlock, Elizabeth B, 1995, Perkembangan Anak, alih bahasa: Tjandrasa dan Zarkasih, (Jakarta: Erlangga.

Jatmika, Sidik, 2009, Pengantin Bom: Sebuah Novel Sosio-Kriminologi, Yogyakarta, Liberplus.

Ma'luf, Louis, 1986, Al-Munjid fi al-lughah wa al-A 'lam, Beirut: Dar al Masyriq.

Munip, Abdul., 2012, "Menangkal Radikalisme Agama Di Sekolah”, dalam: Jurnal Pendidikan Islam, Vol. I, No. 2.

Satiadarma, Monty P. 2004, "Anak-anak Terlantar", dalam Singgih D Gunarsa (Ed)., Dari Anak Sampai Usia Lanjut: Bunga Rampai Psikologi Perkembangan, Jakarta: BPK Gunung Mulia.

Shihab, M. Quraish, 1997Wawasan Al-Quran: Tafsir Maudhu'i atas Perbagai Persoalan Umat, Bandung: Mizan Press. 